\title{
HOW DOES A RETAIL PAYMENT ACCOUNT CONSUMER CHANGES OVER TIME? USAGE RATE BEHAVIORAL SEGMENTATION FROM 2010 TILL 2016 IN THE CZECH REPUBLIC
}

\author{
Ivan Soukal, Jan Draessler
}

\section{Introduction}

Payment account (PA, in plural PAs), as the most common type of the sight deposit, represents a financial product with the highest market penetration in the European Union (EU). The Czech Republic is not an exception. Finclusion study (The World Bank, 2018) showed that PA account penetration is as high as $81 \%$ of all citizens over age 15 in the Czech Republic. EU survey declared the penetration higher by two percent points concerning the population over age 15 in the Czech Republic (TNS opinion \& social, 2016). In spite of a minor methodology difference, such as the inclusion of any financial institution or mobile-moneyservice provider account, it is evident that most of the population possess one or more PAs. EU survey (Eurostat, 2018a) confirmed that most of Czech Republic population aged 16 to 74 actively uses e-banking channel for electronic transactions with a bank for payment or for looking up account information. EU banking regulator acknowledged $\mathrm{PA}$ as the most widespread and therefore important retail financial product for EU consumers (European Banking Authority, 2016). Banks benefit from PA core which is an important source of banks financing (Mejstřík, Pečená, \& Teplý, 2014) gaining importance after the crisis and the following regulation. Study (Centre for European Policy Studies \& Van Dijk MC, 2009) reminded that PA is for the banks the "gateway" product with great importance in terms of establishing the relationship with a consumer as well as obtaining useful marketing data. Regarding PA consumers, both legislative bodies (European Parliament, 2014) as well as researches (Diniz, Birochi, \& Pozzebon, 2012; lqbal \& Sami, 2017; Jones, 2008) saw PA not just as a basic need in economic life but also a mean of preventing socio-economic exclusion in a modern society.
Although, financial service markets are not highly segmented (Lees \& Winchester, 2014), their consumers are. Effective consumer typologies should demonstrate that different segments have unique consumption-relevant attitudes and behaviors (Pires, Stanton, \& Stanton, 2011). Therefore, it plays a key part in the CRM process. This fact along with those from the previous paragraph explains why PA consumer is being studied in many surveys. The scope of the paper is a consumer with PA access via e-banking and their segmentation. E-banking consumer-focused studies aim mostly on demographic status, socioeconomic status, attitudes and behavioral variables other than usage rate. Most of the studies published in the last ten years indexed in the major scientific databases (Web of Science, Scopus and ScienceDirect-Elsevier) are related to the issue of e-banking adoption itself (Adapa \& Cooksey, 2013; Agarwal, Rastogi, \& Mehrotra, 2009; Liébana-Cabanillas, Nogueras, Herrera, \& Guillén, 2013; Rajaobelina, Brun, \& Toufaily, 2013), or in overall electronic services adoption context e.g. (Fonseca, 2014; Zuccaro \& Savard, 2010).

Only a few studies included behavioral segmentation usage rate point of view. However, it was to a very limited extent. They often lack the detail e.g. (Fonseca, 2014) distinguished only user/non-user status, (Zuccaro \& Savard, 2010) did not distinguish the payment instrument. Another issue arises from the average or a single representative consumer approach e.g. in (Hanousek \& Dvorak, 2009). The average consumer is not a correct approach in a differentiated demand environment with segments of a different size. Average consumer approach was not used even in publicly accessible retail banking studies such as (Capgemini, EFMA, \& UniCredit, 2009) and 
other studies by Slovak Banking Association or Scott\&Rose which are even more obsolete. The recentness is the problem of our two papers published in 2011 on the topic. Study (Van Dijk MC \& Centre for European Policy Studies, 2012) suffered from a methodological issue since consumer profile usage rates were only estimations. All previously mentioned studies neglected an aspect described in (Wind, 2008): static/deterministic segmentation tends to ignore segment change. An exception is (Lees \& Winchester, 2014) study which consider this issues of change over time in the consumer acquisition assessment survey. Hence, we claim that there is a gap in empirical evidence.

The main motivation for this study is to provide a proof if and how consumers segments change over time in usage rate features. Among else it would prove if claim about segment change (Wind, 2008) is valid to PA market usage rate segmentation. The evidence is not available at the moment. Recent, detailed (at payment instruments level) survey, with a regard to consumer typology change is not present in three main scientific databases. Usage rate segmentation, which has to be performed prior to answer development over time question, would be useful for a further research. Without detailed consumer profiles studies focused on the PA such as (Hanousek \& Dvorak, 2009; Hedvicakova, 2017; Rod \& Čermáková, 2016) had to use outdated, average consumer profiles or even create only a model profile. Both decreases study quality and could bias results.

The main goal is to identify PA usage rate consumer segments and to find what change they underwent from 2010 till 2016. This way the goal would fill the gap in the form of a detailed behavioral consumer usage rate segmentation with regards to consumer change. The main research question what the consumer segments usage rate characteristics are. Questions related to change over time were transformed into hypotheses:

- H share: market shares of consumer segments are stable over surveyed period.

- H_rate: usage rate of the most important PA services are stable over surveyed period.

To reach goals stated above we performed a data mining on data collected through the PA comparison service "Kalkulátor bankovních poplatkư" (KBP). Analysis sample contained
16,392 records of individual PA usage profiles. The range of services available in KBP was wide. However, the scope of our study are retail core banking services only. Retail core banking services term relates to basic day-to-day needs that are common to all payment accounts in the EU, defined (European Parliament, 2014) as the payment account with basic features.

\section{Literature Search, Data Source, and Methods}

\subsection{Consumer Segmentation}

The diversity of consumers and fierce competition has made it hard to practice mass marketing (Sun, 2009). Therefore, a consumer segmentation, i.e. creation and use of consumer typologies, increased its importance over time. Consumer typologies classify heterogeneous populations into meaningful and distinct subgroups. This provides a starting point for customer profitability calculations and subsequent allocation of marketing resources. From a marketing perspective, consumer typologies provide a basis for more precise and effective segmentation, targeting, and positioning strategies (Yankelovich \& Meer, 2006). Profiles can be employed to develop event-based marketing campaigns while at the same time track and measure the profitability of new service offers (Zuccaro \& Savard, 2010). It also can provide market opportunities identification and a strategy for dealing with competition, limited resources and increasing costs (Sun, 2009).

Behavioral consumer segmentation divides buyers into segments based on their knowledge, attitudes, uses, or responses to a product (Armstrong, Adam, Denize, \& Kotler, 2014). "Uses" variable refers to the goal of the paper: usage rate segmentation. The basic consumer classification usage rate separates consumers into heavy, medium and light users of a specific product (Schiffman \& Kanuk, 2007). Usage rate segmentation variables can enter an analysis in a binary form, e.g. "user/non-user" in (Fonseca, 2014) as well. The segmentation process is consisted of five phases or tasks: to define the research, to design the research, data collection and data analysis, data interpretation (Onwezen, 2018). This paper is focused particularly on the third and then on the fourth phase of the process. Methods employed in the third phase are described in the following subchapter, the fourth phase is 
Tab. 1: Cluster analysis employment in e-banking consumer segmentation

\begin{tabular}{|c|c|c|c|}
\hline Study & Independent variables & Aim & $\begin{array}{l}\text { Number } \\
\text { of clusters }\end{array}$ \\
\hline $\begin{array}{l}\text { Agarwal et al., } \\
2009\end{array}$ & $\begin{array}{l}\text { age, profession, usefulness, } \\
\text { security, trust }\end{array}$ & $\begin{array}{l}\text { What influences consumers } \\
\text { in their usage of e-banking } \\
\text { services. }\end{array}$ & 3 \\
\hline Fonseca, 2014 & $\begin{array}{l}\text { country level: various variables } \\
\text { related to the Internet usage }\end{array}$ & $\begin{array}{l}\text { Identify the position of Portugal } \\
\text { in the EU } 27 \text { in order to study } \\
\text { e-banking user segments. }\end{array}$ & 3 \\
\hline Fonseca, 2014 & $\begin{array}{l}\text { consumer level: social networks } \\
\text { access, online banking usage, } \\
\text { payment services, financial } \\
\text { investments, work, education, } \\
\text { computer and cell phone } \\
\text { possession, Internet connection, } \\
\text { risky behavior features }\end{array}$ & $\begin{array}{l}\text { To identify distinct e-banking } \\
\text { user segments of Portuguese } \\
\text { citizens. }\end{array}$ & 2 \\
\hline $\begin{array}{l}\text { Liébana- } \\
\text { Cabanillas et al., } \\
2013\end{array}$ & $\begin{array}{l}34 \text { socio-demographic and } \\
\text { economic-financial categories }\end{array}$ & $\begin{array}{l}\text { Levels of trust among } \\
\text { electronic banking users } \\
\text { prediction. }\end{array}$ & 3 \\
\hline $\begin{array}{l}\text { Rajaobelina et al., } \\
2013\end{array}$ & $\begin{array}{l}\text { age, gender, trust, satisfaction, } \\
\text { commitment }\end{array}$ & $\begin{array}{l}\text { Online banking customers } \\
\text { classification and describe } \\
\text { their profiles. }\end{array}$ & 6 \\
\hline $\begin{array}{l}\text { Zuccaro \& Savard, } \\
2010\end{array}$ & $\begin{array}{l}\text { Large set of socio-demographic } \\
\text { and economic variables, from } \\
\text { e-banking point of view included } \\
\text { especially internet transactions, } \\
\text { number of bills paid, cumulative } \\
\text { balance in savings account. }\end{array}$ & $\begin{array}{l}\text { To generate the hybrid } \\
\text { segments based on } \\
\text { transaction-based model for } \\
\text { segmenting users of internet } \\
\text { banking. }\end{array}$ & 4 \\
\hline
\end{tabular}

Source: own

a part of the discussion part and conclusion. Statistical methods distinguish between a priori and a posteriori segmentation. This survey is an example of posteriori segmentation which (Berget, 2018) describes as segmentation in which consumers who have similar responses are grouped together, i.e. the segments are identified without using the consumer variables such as age, gender, employment and such.

Studies focused on PA e-banking consumer frequently employed a cluster analysis as the main segmentation method, see Tab. 1 above.

However, there can be seen that only a few of them was focused on usage rate segmentation and mostly analyses inputs were sociodemographic, demographic and such. Usage rate variables related to $\mathrm{PA}$ e-banking usage were in survey (Fonseca, 2014) significantly outnumbered by other services at both country level analysis as well as at Portugal only level analysis. On a country level they adopted the simplest usage rate segmentation approach of whether a certain service (electronic transactions, looking up account information) was used or not. At the country level usage rate of homebanking access (scale metrics) and then several payments related services (binary metrics). Their analysis focused on risk behavior showed that consumers with longer than 6 years usage of e-banking, higher rate of e-banking access (at least once per week), active usage of interbank transfers and other payment services show less risky behaviour (read the warnings, do not respond to an e-mail asking personal data, do not open unknown link, do not go on after page redirection).

Available studies do not provide profiles detailed enough, ignored a possible development over time, could not be applied to the Central European region, were obsolete or usually there was a combination of mentioned issues. The range of services was wide, and 
most of them were not related to PA. Much more precise usage rate profile was presented by the study (Hanousek \& Dvorak, 2009). The study employed "representative client" profile which was used in a PA fee level comparison in Central Europe. The profile itself was not included in the study but it was possible to find it at the author's web. It was detailed to the level of specific payment instruments. Source were consumers in Slovakia, other details concerning an origin, sample size were not available. Therefore, there are two issues. We do not consider an average consumer profile as a correct approach. There were services which were obviously demanded by only a specific consumer profile such as cash services at the desk. High usage frequency in one consumer segment and none in other one result in a mean result with low validity. The same issue appeared in less detailed and obsolete studies by, e.g. Scott \& Rose or public institutions such as the Slovak Banking Association. Average consumer approach was not used even in publicly accessible retail banking studies such as (Capgemini et al., 2009; Van Dijk MC \& Centre for European Policy Studies, 2012). The first one presented different consumer profiles, yet it lacked the detail. Payment instruments were distinguished however there was no information on usage frequency. We sent a question on methods and frequencies to the authors, but a reply was very brief and not helpful. The second mentioned study suffered from the issue that consumer profiles were based on the Blue book database. This data source aggregates services by year frequency or amount. Moreover, in most of the services, the retail banking is not separated from corporate and SME ones. The retail market share had to be roughly estimated.

\subsection{Data Source and Methods}

The data source was the KBP's database of users' individual PA usage. The data were collected from January 2010 till December 2016. KBP input form covers a large variety of services linked to PA. Besides the most widely used ones, it also covers much less demanded services such as cash deposit over the counter, collecting box orders, cash-back etc. KBP is available at https://www.bankovnipoplatky. com/kalkulator.html but please note that the application was replaced by an entirely new version in summer 2018. The total number of downloaded consumer PA usage records was over 52,000. Data gathered were:

- multivariate -48 metric scale and 4 binomial variables concerning PA usage (in the light version 28 only), 4 system variables for a record identification,

- primary - data were gathered directly from the consumer,

- subjective - own subjective seems, data came from consumer himself or herself.

PA services and payment instruments analyzed in the paper match the general international definitions in the second article 2 of (European Parliament, 2014) with the exception of a SIPO collection. SIPO represents a unique type of direct debit pooling offered by a state postal services provider Czech Post state corp. A natural entity can have issued a unique tendigit SIPO code which allows individual direct debits to be pooled, acting like one and being charged as one by the PA provider.

All statistics methods and data preparation described in the paper are available in IBM SPSS Statistics V24 and IBM SPSS Modeler V18 which were both employed to reach the goals. Charts and trend curves were prepared in MS Excel. Records extracted from the KBP database showed varying utility due to the data gathering method - online free of charge comparator with very little input data validation. Therefore, a raw data preparation was a crucial part of the analysis which is consistent with (Nisbet, 2017) suggesting that $60-90 \%$ of the project time may be spent in data preparation activities.

At first, the goal related analysis related to usage rate of PA consumers segmentation. Therefore, there were taken into account variables describing activity intensity only. Variables regarding communication channel preference (e-banking, phone-banking, over the counter services) or demographic status were not part of the analysis. Each usage rate related service was assessed if it had been suitable for the analysis. Histogram assessment proved the problem of some very rarely demanded services and containing extreme values at the same time. For variables with a relatively low mean and a relatively high standard deviation (Nisbet, 2017) sees a low potential for predicting the target. Such variables were excluded from the analysis. Nevertheless, extreme values were found in more frequently demanded services 
Tab. 2: Input variables

\begin{tabular}{l|l|l}
$\begin{array}{l}\text { Minimum month } \\
\text { credit turnover }\end{array}$ & $\begin{array}{l}\text { Domestic ATM withdrawal, } \\
\text { withdrawn amount (another } \\
\text { bank's network) }\end{array}$ & Standing order \\
\hline Average balance & ATM withdrawal abroad & Direct debit \\
\hline $\begin{array}{l}\text { Domestic ATM withdrawal (own } \\
\text { bank's network) }\end{array}$ & $\begin{array}{l}\text { ATM withdrawal abroad, } \\
\text { withdrawn amount }\end{array}$ & Incoming payment \\
\hline $\begin{array}{l}\text { Domestic ATM withdrawal } \\
\text { (another bank's network) }\end{array}$ & Direct payment & \\
\hline
\end{tabular}

Source: own

as well. Although the KBP provides a retail PAs comparison, some of the respondents were obviously freelancers or small enterprises. The number of payments sent or received was in some cases up to 40 per month. Such frequencies are highly unnatural for a retail consumer and do not correspond to profiles in other studies e.g. (Hanousek \& Dvorak, 2009; Zuccaro \& Savard, 2010). In other cases, some of the consumers obviously misplaced usage frequency answer for amount withdrawn answer and vice-versa. Such records were excluded from the analysis. The main sample reduction was done during the imputation assessment. The sample also contained almost empty records suggesting that a user only tested the charges for one specific service or did not finish the form. For such records, the only option was a casewise deletion. The data preparation phase reduced the sample to 16,392 records. Such a reduction is explained by the nature of the data source - comparison tool with free access and very little input for data validation.

Eleven variables were taken as inputs for further parts of the analysis (see Tab. 2). Unlike payments, ATM withdrawals remained separated to a withdrawal from own bank's ATM network and from another bank's network. The difference in withdrawal fees up to $€ 2$ is significantly higher compared to intra and interbank payments difference. Moreover, bank brands are clearly visible on every ATM which allows consumers to distinguish a provider easily.

All variables were observed with a skewed distributions and the inclination of peaks on the left. Then logarithmic transformation was employed. This transformation type is employed in the case of skewness issue (van Schaik, Luan Wong, \& Teo, 2015) and recommended in order to stabilize variance making the distribution closer to the normal one (Meloun \& Militký, 2012).

Interdependence of variables and dimension reduction adequacy was assessed by employment of Kaiser-Meyer-Olkin test for sampling adequacy test (0.624), Bartlett's sphericity test $(p<0.001)$, correlation matrix, and scree plot assessment, see e.g. (Liu, McGree, Ge, \& Xie, 2016; Meloun \& Militký, 2012; Pituch \& Stevens, 2016). The results suggested appropriateness of dimension reduction. Principal component analysis was employed. The method is a standard part of e-banking consumer research employed by e.g. (Adapa \& Cooksey, 2013; Agarwal et al., 2009). Four components were chosen as appropriate solution providing $74 \%$ of total variance explained using a varimax rotation and the lambda value of the fourth component 0.95 .

Two-step cluster analysis was chosen as a segmentation method. SPSS calculation setting were log-likelihood distance measuring, noise handling 0 , assume standardized all variables, CF tree branch limit $8, C F$ tree level limit 5. The number of clusters was set at $3,4,5$, and 6 . Each was analysis result was assessed by silhouette value as a clustering structure indicator and by an interpretation value. The Two-step clustering was employed in the e-banking consumer segmentation by e.g. (Rajaobelina et al., 2013; Zuccaro \& Savard, 2010). The method has two main stages: pre-clustering and clustering. In the first one each observation is assigned into subclusters the other a new subcluster is created. Preclustering procedure is implemented by building a Cluster Feature tree data structure. The CF tree consists of levels of nodes, each consisted of a certain number of records. A leaf entry is 
a final subcluster. The hierarchical approach comes from the principle of BIRCH algorithm (Zhang, Ramakrishnan, \& Livny, 1996) which is very similar to algorithm implemented in SPSS. If the CF tree exceeds the allowed maximum size, it is rebuilt based on the existing CF tree. In the second stage the subclusters are inputs which are grouped into the desired number of clusters by agglomerative clustering algorithm. The method and its implementation in IBM SPSS Statistics is described in a greater detail by (Řezanková \& Löster, 2013). The method is more efficient than widely used k-means method which would result in a calculation with $16,392^{2}$ distance measures.

As mentioned in a previous paragraph, we identified an optimal number of clusters from range of four different solutions accordingly an interpretation value and a silhouette value as an clustering structure indicator, see e.g. (Everitt, 2011; Meloun \& Militký, 2012; Řezanková \& Löster, 2013). The highest value of average silhouette 0.54 was achieved for a solution with three clusters which was chosen as an optimal one also in e-banking consumer clustering of studies (Agarwal et al., 2009; Fonseca, 2014; Liébana-Cabanillas et al., 2013). Post-analysis result confirmation was performed on a selected part of the dataset as (Meloun \& Militký, 2012) suggested.

Chi-square test was employed to test an independence of shares of each cluster on time, i.e. whether market shares of consumer segments are stable over surveyed period or not. Chi-square is widely used method which was employed in e-banking consumer study (Agarwal et al., 2009). Method is based on analyzing data in a contingency table by comparing the actual cell frequencies to an expected cell frequency (Hair, 2014).

MANOVA was employed to test if means for the most important variables of all groups are equal, i.e. if vectors of year means for variables of the most important factors are the same. MANOVA allows testing of group differences across multiple metric dependent variables simultaneously. Tested treatment is in this case time in years. Method is closely described in (Hair, 2014; Meloun \& Militký, 2012).

Linear regression based on the least square method (Meloun \& Militký, 2012; Nisbet, 2017) was employed to describe the development of variables over time. We did not employ other than linear regression function due to a short time series. We employed a coefficient of determination to assess the linear trend function accuracy.

The methods and software described above were employed to answer these:

1. research question to identify usage rate consumer segments,

2. hypotheses related to change over time:

a) H_share: Market shares of consumer segments are stable over surveyed period.

b) H_usage: Usage rate of the most important PA services is stable over surveyed period.

\section{Results}

\subsection{Usage Rate Segmentation}

The sample of 16,392 individual PA usage records has underwent dimension reduction by PCA method resulting in four components. Twostep cluster analysis was employed to perform segmentation based on the components resulting in three-cluster solution, see tables below.

Tab. 3 shows that the first and the fourth components influenced segmentation the most since the difference in SPSS predictor importance index is very high. The first component almost perfectly correlated with variables Domestic ATM withdrawal (another

Tab. 3: Components relative importance and centroids coordinates

\begin{tabular}{c|c|c|c|c} 
Component & $\begin{array}{c}\text { Predictor } \\
\text { importance }\end{array}$ & Cluster 1 & Cluster 2 & Cluster 3 \\
\hline 1 & 1.00 & -0.721 & 1.310 & -0.014 \\
\hline 2 & 0.04 & -0.041 & 0.087 & -0.041 \\
\hline 3 & 0.03 & -0.034 & 0.018 & 0.137 \\
\hline 4 & 1.00 & 0.276 & 0.216 & -2.275 \\
\hline
\end{tabular}


bank's network) 0.965 and Domestic ATM withdrawal, $€$ amount withdrawn (another bank's network) 0.961 . The first component was the most important in the first and the second cluster segmentation. The fourth component correlated with variables Average balance, $€$ amount -0.781 and Domestic ATM withdrawal (own bank's network) 0.704. The fourth component was the most important for the third cluster.

The first cluster was separated from the others mainly by the exclusive preference of own bank's ATM network. The next difference is related to the average balance which the highest one. That is in sharp contrast to the third cluster with the average balance below zero and in less sharp contrast to the second one with the average balance lower by $20 \%$. Overall activity was the lowest one with the highest relative difference to the second cluster in ATM withdrawal abroad frequency, yet the absolute difference was five withdrawals per year only.

The most different usage pattern of the second cluster was associated with ATM utilization. Domestic withdrawals were made regardless of the ATM's network owner. Domestic ATM usage frequency was almost doubled in total, and abroad ATM usage was multiple times higher compared to other two clusters although, in absolute usage frequency it is a less sharp difference. The withdrawn amount was the highest one for both domestic one $(€ 106)$ and abroad one (€179). Overall activity was the highest although, with the exception of the ATM usage, it was still similar to other clusters.

The third cluster's most unique feature was related to average balance level which was below zero. This variable is described in greater detail in the next sub-chapter. ATM usage was less frequent compared to the second cluster by approximately $50 \%$ regarding both variables: the withdrawals frequency as well as the amounts withdrawn. The activity in remaining services is close to the second cluster making the overall activity average. Most of the consumers in the third cluster declared balance close to zero, see Fig. 1 below for an average balance overview.

The $\mathrm{x}$-axis scale was set at $5,000 \mathrm{CZK}$ step, which approximately equals to $€ 185$. This step was chosen accordingly the study of

\section{Tab. 4: PA consumer usage rate profiles}

\begin{tabular}{l|r|r|r}
\multicolumn{1}{c|}{ Variable } & Cluster 1 & Cluster 2 & \multicolumn{1}{c}{ Cluster 3 } \\
\hline Count (\%) & $9,497(57.9 \%)$ & $5,243(32.0 \%)$ & $1,652(10.1 \%)$ \\
\hline Minimum month credit turnover, $€$ amount & 830.0 & 942.9 & 714.1 \\
\hline Average balance, $€$ amount & $1,386.9$ & $1,121.3$ & -19.9 \\
\hline Domestic ATM withdrawal (own bank's network) & 2.8 & 3.1 & 3.5 \\
\hline Domestic ATM withdrawal (another bank's network) & 0.0 & 2.1 & 0.9 \\
\hline $\begin{array}{l}\text { Domestic ATM withdrawal, } € \text { amount withdrawn } \\
\text { (another bank's network) }\end{array}$ & 0.0 & 106.6 & 61.4 \\
\hline ATM withdrawal abroad & 0.2 & 0.5 & 0.2 \\
\hline ATM withdrawal abroad, $€$ amount withdrawn & 150.4 & 179.0 & 92.0 \\
\hline Direct payment & 6.5 & 7.9 & 7.6 \\
\hline Standing order & 3.7 & 4.3 & 4.7 \\
\hline Direct debit & 1.5 & 1.6 & 1.7 \\
\hline Incoming payment & 3.9 & 4.6 & 3.8 \\
\hline
\end{tabular}

Source: own

Notes:

- usage frequencies are per month;

- amounts in EUR are converted by the exchange rate valid at the end of the survey period December 2016: $E U R / C Z K=27$ (EUR is the base currency);

- ATM withdrawal amount represents the amount withdrawn per one draft;

- standing order and direct debit payments are outgoing payments only without newly established and modified ones. 


\section{Finance}

\section{Fig. 1:}

Average balance histogram (log y axis) up to $€ 3,700$
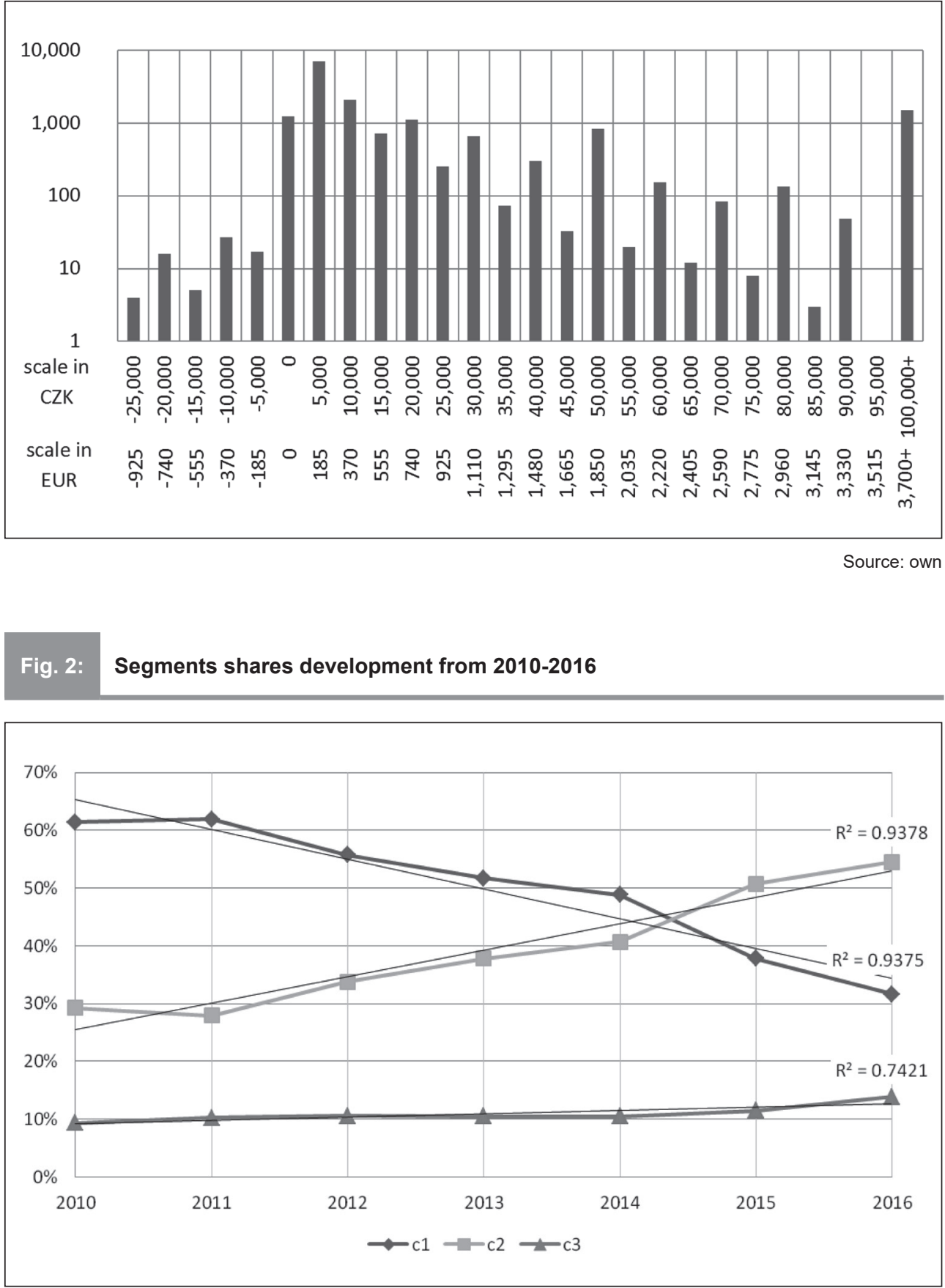
rounding tendencies (Coupland, 2011) and to provide more detailed view. Fig. 1 shows that almost $7.5 \%$ of the consumers declared their average balance to be a bit more than zero or below zero. The ones with the balance below zero were exclusively members of the third cluster. Approximately $9 \%$ of the consumers were on the other side of the balance histogram declaring the balance of 100,000 CZK (around $€ 3,700$ ) or higher. These consumers were from the first and the second cluster only.

\subsection{Market Demand Change over Time}

The first hypothesis was related to the market shares of each identified cluster. The chisquare test in contingency table showed $p$-value $<0.001$. Hence, there was enough of statistical evidence to reject hypothesis $\mathrm{H}$ _share that market shares of consumer segments are stable over surveyed period. The shares manifested statistically significant instability in surveyed years, see Fig. 2 .

Two major contradictory trends were identified in the seven-year time series. The first cluster showed a stable and significant degressive trend which was described by the linear regression function with the slope
-0.052. The downward trend was characterized by a high coefficient of determination $94 \%$. The second cluster manifested stable progressive trend formalized by linear trend function with the slope 0.046 and almost the same coefficient of determination as of the first one. At the beginning of the survey, the first cluster represented the dominant consumer profile with a share above $60 \%$. The second cluster was representing a smaller set of consumers with higher usage rate and a wider range of demanded services. The year 2015 meant the change in a dominant consumer profile due to a market share loss of approximately $5 \%$ per year and $4.6 \%$ share gain per year regarding the second one. The trend seems straightforward and closely following the trend curve with the exception of the first year. The last six years show no obvious sign of the decrease in the rate of change. The third cluster's share appeared to be a stable and minor one. The only exception was the last year of the survey when 2.3 percent points were gained. Despite this increase, the trend still showed a high coefficient of determination of $74 \%$ showing only a slow increase described by the regression function slope 0.006 .

\section{Fig. 3: ATM withdrawal usage frequency per month development from 2010-2016}

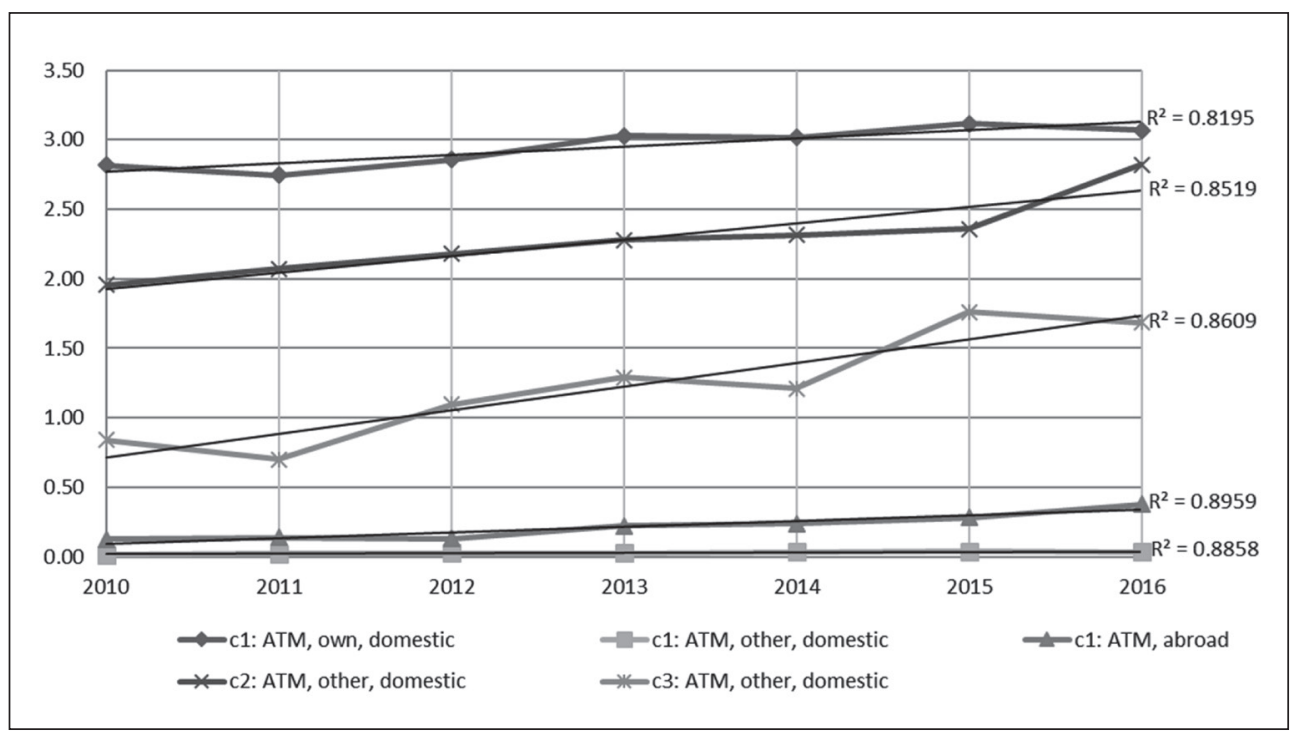


The second hypothesis was related to usage rate stability of the most important variables. For each cluster the hypothesis $\mathrm{H}$ _usage that usage rate of the most important PA services is stable over surveyed period was tested. For each cluster there was enough of statistical evidence to reject the hypothesis with $p$-values $<0.001$. Direct ATM utilization and direct payments showed a steady trend of change (except ATM withdrawal in the third cluster). Along with some degree of variability in other variables it was the cause and evidence of usage rate changes over time. Steady trend and also real-world difference were observed in the domestic ATM withdrawals development, see Fig. 3.

The first cluster showed a slight but steady trend of a usage rate increase of domestic ATM withdrawals per month (own bank's network) and for ATM withdrawals abroad. There can be seen an increase a bit more than three withdrawals per year over the surveyed seven years. ATM withdrawal from other bank shows long-term avoidance of first consumer cluster with only residual values in hundredths implying that almost all consumers did not seek other ATMs than their own bank's network. The second and the third cluster, on the contrary, manifested for this variable steady increasing trend throughout the whole time-series. The loyalty to the ATM network of their own bank is significantly lower compared to the first cluster and it is getting weaker each year. The month withdrawal frequency increased for both clusters by almost 1 withdrawal per month over the surveyed years.

After the most important variables were tested, the rest of variables was analyzed as well. Variables Standing order and Collection acted almost as constants. Most of the services showed some degree of variability that did not result in trend or was negligible. The only exception was an instrument of direct payments. Although a variability is greater than one which could be seen in case of domestic ATM withdrawals, the trend suggests that all cluster showed a gradual increase of usage rate per month, see figure below. The first cluster increased its usage rate by 1.5 payment per month over the surveyed period. The most active cluster's (second one) increase was slightly over 0.5 payment per month. This development diminished a difference in payment activity which was among clusters approximately 2 payments per month at the beginning of the survey. The lowest direct payments usage rate was at the end of the survey period at the same level as the most active cluster at the beginning in 2010 .

\section{Fig. 4: Payment usage frequency per month development from 2010-2016}

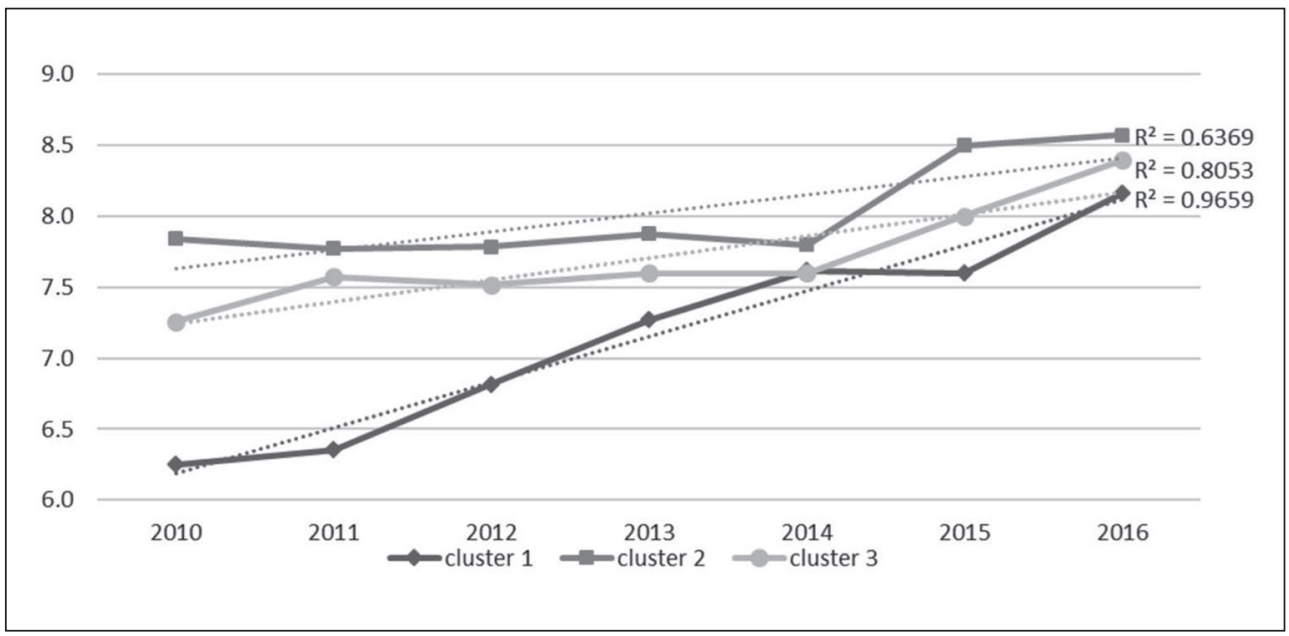




\section{Discussion}

\subsection{Segmentation Interpretation}

At first, the research question concerning the usage rate segmentation will be discussed. We interpret the first cluster as a "price driven less active consumer". The main feature is exclusive preference regarding the ATM usage of his bank's brand network. However, the term brand loyal consumer is not adequate because the meaning would not be the same as in financial service brand loyalty surveys such as (Tahal, Formánek, \& Mohelská, 2017). Although the consumer strictly prefers the ATM services provided by his/her PA provider, it might not mean that the consumer is loyal to the brand itself. A consumer might switch among banks and still prefer using only actual PA provider's ATM network since it is a "service type" loyalty, not a brand one. We assume that the fees are the main reason for distinguishing the ATM networks. Three largest universal retail banks Česká sporitelna, plc. (Erste group), Československá obchodní banka, plc. (KBC group), and Komerční banka, plc. (Societé Generale group) distinguished in surveyed years whether withdraw is from their own network or not. The consumers' motivation is then most likely to be the charge avoidance since the charge could be as high as $€ 2$ per one draft. Therefore, we interpret the first cluster as "price driven" or "charge-aware" segment. We further expect these consumers to be mostly the clients of previously mentioned largest universal banks. The reason is that low-cost and other mainly electronic-services oriented banks do not distinguish, respectively do not charge, ATM withdrawals from own and other banks' network for several years now. The overall activity of the cluster is the lowest regarding the usage rate of almost all analyzed services however the absolute difference is in not sharp contrast to other clusters. Therefore, we choose more appropriate "less active" term in the cluster title. There cannot be observed such a significant difference in activity between clusters as found by (Zuccaro \& Savard, 2010). However, the study segmented the sample into higher number of clusters leaving a greater possibility to separate a highly active users into a small cluster. Moreover, (Zuccaro \& Savard, 2010) performed an aggregated analysis i.e. the sum of the total month transaction made through e-banking per month regardless of the instrument.
We interpret the second cluster as an "active consumer". The term active stands here for both the range of services as well as for the usage rate. There are at least two possible reasons for using all the services we monitored. The first possible explanation is that the consumers in the second cluster are clients of banks which do not charge or distinguish ATM withdrawals from own and from another bank's network. This is typical for low-cost and other mostly e-services oriented banks. The second group of consumers could be possessing PAs with a conditional sale regarding ATM withdrawal from another bank's network. Such conditional sales on ATM withdrawals are common in the Czech Republic and they are applied in case if credit turnover is higher than a certain amount, debit card usage per month or an amount spent by the card per month reach a certain limit. More than half of the banks on the market offer some kind of PA conditional sale. This share was significantly lower at the beginning of the survey in 2010. The second possible explanation is that these consumers do not care much about the fees at all because they are active cash-users. The second option would be supported by the highest amounts withdrawn from other bank's ATM home as well as abroad. This consumer profile became the mainstream one in 2015 . A new Czech mainstream consumer is then more active. It is in accordance to a continuous increase of e-banking based payments. Yearto-year increase of amount transferred was 9.5\% (Czech National Bank, 2018a) at the end of the surveyed period. Although the amount per transfer might have been increased, we expect the increase was caused by higher frequency as well. The active profile showed the highest minimum credit turnover and the highest share of high credit turnover consumers as well. Results of study (Fonseca, 2014) suggest that this cluster might be consisted of consumers with less risky behavior since the wider and more frequent was the usage of e-banking, then the probability of being in less risk behavior cluster rose. It suggests that in this cluster consumers tend less to respond to e-mail asking personal data, they read the warnings, do not open unknown link, do not go on after page redirection etc.

The last cluster can be interpreted as a "low-balance/overdraft user with average activity". The most unexpected result was how many consumers declared their average 
balance at zero or below. The zero balance can be explained by the rounding tendencies (Coupland, 2011). The overall preference for a zero value as an expression of "almost nothing" is very common. We assume the consumers tend to declare they have just some money, a small amount of money. Almost three-quarters of consumers in the third cluster declared their average balance in the interval from $€ 0$ to $€ 185$. Such a low balance is in general related to a student status or low-income consumers. Students are also specific segment due to highly irregular incomes and sometimes no income at all. This would correspond to the fact that the third cluster had the highest number of consumers declaring zero as their minimum credit turnover. It indicates that an income is irregular, and, in some months, there is none. Low-income employees or individuals relying on social welfare benefits spend a great part of their wage and in general, tight family budget leaves not much chance to have other than very low balance before the payday. An alternative explanation of zero balance would be that consumers declare zero intentionally to exclude a specific type of conditional sales. KBP would not apply maintenance fee conditional sales related to the balance if the balance is set at zero. This way a consumer would obtain an overview of PA prices unbiased by such conditional sales. Yet, as a monetary policy drastically changed during the post-crisis years, the Czech banks did not seek to attract more liquidity anymore. The banks, mostly subsidiaries of parent banks abroad, were overcapitalized (Derviz \& Raková, 2012), capital adequacy, amounts of deposits were significantly over the safe ratios (Czech National Bank, 2018b). Therefore, conditional sales related to the account balance disappeared from the price lists completely or were replaced by a total amount invested in a bank. We assume then that a demand for comparison with no regard to balance may be valid, but an effect is negligible and only during the 2010-2013 period. The third cluster also contains consumers declaring a negative balance. This would suggest overdraft users however their share is $4 \%$ only. The share on the total sample is almost $0.5 \%$ meaning that every $200^{\text {th }}$ consumer in our sample was drawing from the overdraft facility on credit. It is worth mentioning that credit turnover mean is lower by $25 \%$ compared to the active consumer cluster. We are aware that more detailed study is needed in order to suggest that lower turnover leads to overdraft usage or generally increases the propensity to take a consumer loan. Although loans are beyond the scope of our study this finding could be also related to adoption of western-type financial products usage e.g. in the United Kingdom is very common to use authorized overdraft as a kind of a financial buffer.

\subsection{Development over Time}

The next part of the goal is consisted of two hypotheses related to the question of development over time. Identified consumer typologies were not stable over time in both the shares on total and in usage rate of the most important variables. The development showed an ongoing change of what can be considered as a mainstream profile. The largest cluster of price-driven consumers was dominating from 2010 to 2014. It was then replaced in 2015 by the active consumer profile. Fig. 2 might suggest that this "price driven less active consumer" segment's share will continue to shrink however the development in such way cannot continue for much longer. There are at least two possible scenarios to be taken into consideration. The first one takes place in a situation if large universal retail banks will be charging an extra fee for other bank's network ATM withdrawal. Then we can expect that some consumers from the first cluster will be switching to other providers with no or with no extra fees for ATM withdrawal from other bank's network. This trend would continue until only the large universal banks' brand loyal consumers would remain and the decrease will likely to end in a convex curve stabilizing at some point. The second possible scenario relates to a situation when large universal retail banks would stop distinguishing own/other ATM network in order to stop price-sensitive consumers loss. Some evidence can be already seen in the pricelists. One of the largest retail banks on the market Československá obchodní banka plc. introduced after this survey PA product "Plus Konto". It offers ATM withdrawals for free regardless of the ATM network although there is a general maintenance fee with a conditional sale. If this example would be followed, then it would lead to a new situation because one the most typical usage pattern would disappear. Nevertheless, there is no evidence supporting 
this scenario so far. We find the first scenario more probable. It is due to the extent of three main universal banks ATM networks, their significant share on the market and the pricelists where most of the offered PAs got different charges own versus another banks' ATM networks even now.

ATM withdrawals and direct payments showed a steady trend of usage rate increase significant enough not just statistically but also from the real-world point of view. Identified increase in the domestic ATM withdrawals was rather surprising. The statistics (Czech National Bank, 2018a) confirms the continuous trend of card payments increase which would suggest a shift of consumer preference from cash to card payments. Yet, Czech consumer still prefers some cash which is withdrawn from ATMs regardless of the consumer segment. A possible explanation is related to ATM withdrawal fees reduction (already commented in paragraphs above) which occurred in the last ten years and the ATM network. The network extends each year which can be tracked in Financial market supervision reports (Czech National Bank, 2018b). Consumer withdraws cash more frequently as ATMs are cheaper to use and more at disposal. An increase was found also at ATM withdrawals abroad. It is logical to presume that a consumer uses three more withdrawals abroad per year due to the ATM fees reduction trend. Some banks even started to offer ATM withdrawal abroad under the same conditions as they apply to domestic ATM withdrawal. An example is, e.g. mBank, plc., which now does not distinguish domestic and abroad ATM withdrawals if a consumer withdraws more than $€ 55$. Equa bank plc. offers this service for fixed fee of $€ 0.3$ only. Other banks offer more favorable fees as well but usually, it is in form of conditional sale related to a card type, credit turnover etc. Yet, the regression analysis would be adequate to confirm this expectation. Therefore, we suggest testing and analyze a hypothesis that ATM withdrawal fees and usage frequency have a negative correlation. Regression analysis would be beneficial in this case to examine e.g. an issue related to consumer lack of interest in the fees since PA charges. The reason is that they might be negligible compared to consumers' incomes. Also, change in fees might be noticed by consumers with a significant delay. ATM withdrawals abroad also allow taking less cash on departure for a vacation or shopping trips. The increase of direct payments across the segments suggests increased economic activity which accordance with the business cycle during the 2010-2016 period. Consumers increased their shopping activities as financial crisis turned into growth again. Eurostat shows a noticeable increase in an e-commerce turnover over 2007-2017 period (Eurostat, 2018c), the percent of internet purchases by individuals increase (Eurostat, 2018b) and there is an overall adoption of shopping habits common in Western Europe. Such habits include e.g. grocery shopping via internet instead of a personal mall visit and credit transfer payments instead of cash payment at the cash desk. The banks are also trying to increase consumer's satisfaction with more user-friendly e-banking making payments an easier task. Nevertheless, another study focused on payment preference would be beneficial to confirm the increase of payment activity and the overall shift from cash to instruments such as mobile payments, NFC modules, and such tools. It is a similar problem to e-banking consumer studies. They are almost exclusively focused on an adoption issue instead of a usage pattern.

\subsection{Application and Data Remarks}

The identified profiles could provide test profiles for various applications. The profiles can be used in the information quality testing of PA comparison websites. The directive 2014/92/ EU and its transposition in the national legal systems should ensure that consumers have access, free of charge, to at least one website comparing fees charged by payment service providers. Such websites should provide accurate and up-to-date information (European Parliament, 2014). Nevertheless, there is no detail and neither guidance how this feature should be tested. The transposition of the directive in the Act. 452/2016, Coll. is mostly a translation which again provides no detail on accuracy and being up-to-date verification issue. We suggest using our profiles as a base for such testing. Czech Trade Inspection Authority published the list of the websites which comply the conditions of (European Parliament, 2014) in November 2018. So far, there is just one such service. Yet, there is no answer to a question on which information quality testing methodology was adopted in order to include the website 
on the list. The profiles can be also used for pricing indices construction, i.e. weighted price indices of PA fees should be updated. The paper (Rod \& Čermáková, 2016) presents such a comparison for the year 2011 and 2014. Authors expected that market situation would be stable for five years. However, our results proved that the market is undergoing a constant change in shares and typologies. The first cluster lost $10 \%$ of its size and on the other hand, the second one gained $10 \%$ during the 2010-2014 period. Therefore, their price index weights should have been updated in order to reflect the change in the demand. The next possible issue of such indices rises from change within the profiles itself. It is true that only ATM usage and payments manifested a real-world change. Therefore, we agree with (Rod \& Čermáková, 2016) that market prices structure changed but we claim that their results were slightly biased due to an assumption of no demand structure change in 2010-2014 period. Study (Hedvicakova, 2017) assesses the bank offer based on two model profiles: inactive and active one. Although mainly inactive profile seems plausible, there is no indication from where the usage rate for active profiles were derived from. Hence, our profiles could provide data for the model employed in the study.

Fig. 1 clearly shows a phenomenon of figure rounding tendency used in money amounts estimation. This tendency is natural and in accordance with other research. Large scale study (Coupland, 2011) showed that there is a significantly higher frequency of round numbers on the web than it would be expected accordingly the statistical distribution. Histogram showed clear spikes for each round number but numerals ending with 5 shared something of the same quality. Our findings confirmed this conclusion however it is necessary to keep in mind that consumers counted in CZK and so the decadic and quinary rounding preference cannot be observed in $€$ amounts (EUR/CZK = 27). The same pattern where eight pairs of values are in a specific order can be observed for amounts from $€ 720$ to $€ 3,330$. However, the quinary rounding is preferred less than decimal. Amounts in CZK 15,000, 25,000, 35,000,... are becoming significantly less frequent than ten-rounded amounts 20,000, 30,000, 40,000 ... CZK, see Fig. 1. A similar tendency was found among amounts over 100,000 CZK. The only difference was only in ten-times higher step: 50,000 and
100,000 CZK. A similar issue was studied by (Lynn, Flynn, \& Helion, 2013) concerning the prices and in the field of multi-dimensional prices by (Estelami, 1999), which is the similar problem to PAs and their complex tariffs in the Czech Republic. Study of such phenomenon might provide a guide on how to estimate amounts from rounded responses. Consumers may not have the same pattern of rounding even not following mathematical rules.

The question of primary data reliability has to be commented on. The KBP's database holds a unique dataset that is virtually impossible to obtain by conventional market survey methods due to very high costs. Moreover, individual motivation and gain have to be taken into account. Why any consumer uses a comparison tool? The market overview calculated by the KBP is highly personalized. Consumer's selfinterest drives respondent to give as accurate data as he/she can. It is in the respondent's best interest since the results would be otherwise of no use. There is a possibility to test or demand a survey that reflects only a particular service such as ATM withdrawals. However, such "one-service" queries were excluded during the data preparation phase. Therefore, we presume that the data reliability is in our case even better than in common questionnaire surveys. We claim that the only source of more reliable data is banks' records. This is rather unusual since the primary data is considered more reliable and valid that secondary ones (Windle, 2010). Yet in this case it is true. There is a space for an estimation error and bias, e.g. due to a rounding. It is worth mentioning that it is virtually impossible to obtain banks' records and so chosen method of data gathering is probably the best one available.

\section{Conclusion and Limitation}

The goal was to identify PA usage rate consumer segments and to find what change they underwent from 2010 till 2016. The study's ambition was to fill the gap in empirical evidence of PA consumer profiles with regards to consumer change over time. The primary goal of behavioral usage rate segmentation was performed on the sample of primary data containing 16,392 individual PA usage records. The records were gathered from 2010 till 2016 via online comparison tool KBP. Consumers were segmented by the two-step cluster analysis of variables: minimum credit 
turnover, average account balance, various ATM utilization, and outgoing payment instruments. Three consumer segments with PA access via e-banking were identified: pricedriven less active consumer, active consumer and low balance/overdraft user with average activity. ATM withdrawals and average account balance were the most separation-responsible variables. The price-driven cluster showed an exclusive preference for ATM of own bank's network highly probably due to a fee policy. The overall activity compared to the most active segment was lower mostly by $20 \%$ and less with an exception of ATM usage abroad where the difference was much more significant. The active consumer segment was characterized by higher overall activity and no exclusive preference of ATM withdrawals from the ATM of own bank's network. The third segment was a lesser one. This segment differed mainly by the average account balance slightly below zero suggesting an inclusion of consumers with an overdraft facility. The rest of the analyzed variables showed average values.

There were rejected both hypotheses to a development over time. Neither of segments share or the most important variables (especially ATM withdrawals) were stable over time. There can be observed a gradual change in both features. Price-driven typology represented the major consumer segment from 2010 with the market share of $60 \%$ till 2014 . Then the active consumer segment became dominant changing the mainstream consumer into the profile with higher activity and different ATM usage pattern. At the end of the surveyed period the first segment lost almost half of its size to the favor of the second one. The third segment was a lesser one with stable market share slightly over $10 \%$. All clusters showed an increasing trend in ATM usage. Price-driven cluster steadily increased ATM withdrawal abroad from technical zero to 0.4 which was in sharp contrast to almost constant usage of domestic ATM withdrawals or ATM abroad usage by the low balance/overdraft user cluster. Active profile and low balance/overdraft user increased domestic ATM usage by almost one withdrawal per month. The trend can be explained by the changes in the banks' fee policy, ATMs' network improvements, and in a case of abroad ATM withdrawals also a preference to exchange only as much cash as needed at the place of vacation of shopping. Direct payments shared trend of increase in average by one payment per month, in a case of the price-driven profile by two. The development can be explained by the increase in shopping activity via internet and by the change in a business cycle when crisis turned into growth and upswing.

The study showed that PA consumer segments underwent significant development. Therefore, we suggest not to rely on one and even static "representative consumer" profile in PA studies. We also suggest using our profiles as a base for PA comparison websites information quality testing. The identified increase of ATM withdrawals suggests a future study on an impact of fees i.e. a hypothesis that consumer reacts on a tariff change. We would appreciate any other researcher to perform the analysis on a similar set of data from another country to compare the results or establish cooperation for a deeper study to further shed light on described development. The propensity to round figures related to amounts of money was found mainly regarding to average balance. We suggest performing a rounding experiment to provide a better insight which would allow a more detailed and realistic overview.

We limit the interpretation of results to PA consumers with access to the Internet, PA access via e-banking, possessing at least the basic level of ICT literacy and speak Czech. The sample represents the majority of PA consumers in the country (Czech National Bank, 2018b). Authors of a PA pricing study (Hanousek \& Dvorak, 2009) claimed that regarding the Czech Republic, Slovakia and Poland there are important similarities in the behavior of bank clients in relation to banks. This suggests that our results may describe the situation in Central Europe and not just in the Czech Republic. Nevertheless, we rather limit the results to the Czech Republic since the claim from 2009 may not be valid anymore. It could be due to the development we observed in our survey - mainstream consumer transformation. Secondly, even the basic ration of PA penetration started to diverge since 2012: Czech Republic 81\%, Slovak Republic 84\%, Poland $87 \%$ (The World Bank, 2018).

The study was supported by the Specific Research Project (2019) at the Department of Economics of Faculty of Informatics and Management of the University of Hradec Kralove. We would like to thank Lucie Elza 
Knourkova for her help with the Calculator database. We would like to appreciate a longterm cooperation with Patrik Nacher and his continuous effort in consumer education and protection.

\section{References}

Adapa, S., \& Cooksey, R. (2013). Factors affecting consumer's continued use of internet banking: Empirical Evidence from Australia. Australasian Journal of Information Systems, 18(1), 5-31. https://doi.org/10.3127/ajis.v18i1.751.

Agarwal, R., Rastogi, S., \& Mehrotra, A. (2009). Customers' perspectives regarding e-banking in an emerging economy. Journal of Retailing and Consumer Services, 16(5), 340-351. https://doi.org/10.1016/j. jretconser.2009.03.002.

Armstrong, G., Adam, S., Denize, S., \& Kotler, P. (2014). Principles of Marketing VS. Sydney: Pearson Education Australia.

Berget, I. (2018). Statistical Approaches to Consumer Segmentation. In Methods in Consumer Research, Volume 1 (pp. 353-382). https://doi.org/10.1016/B978-0-08-1020890.00014-5.

Capgemini, EFMA, \& UniCredit. (2009). World Retail Banking Report 2009. Retrieved from https://www.capgemini.com/wp-content/ uploads/2017/07/World_Retail_Banking_ Report_2009.pdf.

Centre for European Policy Studies, \& Van Dijk MC. (2009). Tying and other potentially unfair commercial practices in the retail financial services sector. Retrieved from http:// ec.europa.eu/finance/consultations/2010/tying/ docs/report en.pdf.

Coupland, N.(2011). Howfrequentarenumbers? Language \& Communication, 31(1), 27-37. https://doi.org/10.1016/j.langcom.2010.09.001.

Czech National Bank. (2018a). ARAD - Time Serie System. Retrieved December 8, 2018, from https://www.cnb.cz/cnb/STAT. ARADY_PKG.STROM_KOREN?p_lang=EN.

Czech National Bank. (2018b). Financial market supervision reports. Retrieved January 29, 2019, from https://www.cnb.cz/ en/supervision_financial_market/aggregate_ information_financial_sector/financial_market_ supervision_reports/index.html.

Derviz, A., \& Raková, M. (2012). Parent Influence on Loan Pricing by Czech Banks. Prague Economic Papers, 21(4), 434-499. https://doi.org/10.18267/j.pep.433.
Diniz, E., Birochi, R., \& Pozzebon, M. (2012). Triggers and barriers to financial inclusion: The use of ICT-based branchless banking in an Amazon county. Electronic Commerce Research and Applications, 11(5), 484-494. https://doi.org/10.1016/j.elerap.2011.07.006.

Estelami, H. (1999). The computational effect of price endings in multi-dimensional price advertising. Journal of Product \& Brand Management, 8(3), 244-256. https://doi. org/10.1108/10610429910272547.

European Banking Authority. (2016). Consultation Paper EBA/CP/2016/13 EBA Draft Regulatory Technical Standards. Retrieved December 14, 2018, from https://eba.europa. eu/documents/10180/1586509/EBA-CP-2016$13+$ Consultation+Paper+on+draft+RTS+and+I TSs+under+PAD.pdf.

European Parliament. (2014). Directive 2014/92/EU of the European Parliament and of the Council of 23 July 2014 on the comparability of fees related to payment accounts, payment account switching and access to payment accounts with basic features.

Eurostat. (2018a). Individuals using the internet for internet banking: \% of individuals aged 16 to 74 . Retrieved November 23, 2018, from https://ec.europa.eu/eurostat/tgm/ table. do? tab $=$ table \&init 1 \&language $=$ en \& pcode $=$ tin 00099\&plugin $=1$.

Eurostat. (2018b). Internet purchases by individuals. Retrieved January 18, 2019, from http://appsso.eurostat.ec.europa.eu/nui/show. do?dataset=isoc_ec_ibuy\&lang=en.

Eurostat. (2018c). Share of enterprises' turnover on e-commerce. Retrieved January 18, 2019, from https://ec.europa.eu/eurostat/ tgm/table.do?tab=table\&init=1 \&language $=e n \&$ pcode $=$ tin00110\&plugin $=1$.

Everitt, B. (Ed.). (2011). Cluster analysis (5th ed.). Chichester, West Sussex, UK: Wiley.

Fonseca, J. R. S. (2014). E-banking culture: A comparison of EU 27 countries and Portuguese case in the EU 27 retail banking context. Journal of Retailing and Consumer Services, 21(5), 708-716. https://doi.org/10.1016/j.jretconser.2014.05.006.

Hair, J. F. (Ed.). (2014). Multivariate data analysis (7th ed.). Harlow: Pearson.

Hanousek, J., \& Dvorak, P. (2009). Paying for Banking Services: What Determines the Fees? SSRN Electronic Journal. https://doi. org/10.2139/ssrn.1479915.

Hedvicakova, M. (2017). Key study of bank accounts for young people with using multi- 
criteria optimization and fuzzy analysis. Applied Economics, 49(36), 3599-3610. https://doi.org/ 10.1080/00036846.2016.1265073.

Ho, R. (2014). Handbook of univariate and multivariate data analysis with IBM SPSS (2nd ed.). Boca Raton: CRC Press, Taylor \& Francis Group.

Iqbal, B. A., \& Sami, S. (2017). Role of banks in financial inclusion in India. Contaduría y Administración, 62(2), 644-656. https://doi. org/10.1016/j.cya.2017.01.007.

Jones, P. A. (2008). From tackling poverty to achieving financial inclusion-The changing role of British credit unions in low income communities. The Journal of Socio-Economics, 37(6), 2141-2154. https://doi.org/10.1016/j. socec.2007.12.001.

Lees, G., \& Winchester, M. (2014). Do customer profiles change over time? An investigation of the success of targeting consumers of Australia's top 10 banks 2009 and 2011. Journal of Financial Services Marketing, 19(1), 4-16. https://doi.org/10.1057/ fsm.2013.26.

Liébana-Cabanillas, F., Nogueras, R., Herrera, L. J., \& Guillén, A. (2013). Analysing user trust in electronic banking using data mining methods. Expert Systems with Applications, 40(14), 5439-5447. https://doi. org/10.1016/j.eswa.2013.03.010.

Liu, S., McGree, J., Ge, Z., \& Xie, Y. (2016). Finding groups in data. In Computational and Statistical Methods for Analysing Big Data with Applications (pp. 29-55). https://doi. org/10.1016/B978-0-12-803732-4.00003-9.

Lynn, M., Flynn, S. M., \& Helion, C. (2013). Do consumers prefer round prices? Evidence from pay-what-you-want decisions and selfpumped gasoline purchases. Journal of Economic Psychology, 36, 96-102. https://doi. org/10.1016/j.joep.2013.01.010.

Mejstřík, M., Pečená, M., \& Teplý, P. (2014). Banking in theory and practice. Praha: Karolinum.

Meloun, M., \& Militký, J. (Eds.). (2012). Statistical data analysis: a practical guide (Reprinted). New Delhi: WPI, Woodhead Publ. India Pvt. Ltd.

Nisbet, R. (2017). Handbook of statistical analysis and data mining applications (2nd ed.). Waltham, MA: Elsevier Inc.

Onwezen, M. (2018). Including Context in Consumer Segmentation. In Methods in Consumer Research, Volume 1 (pp. 383-400). https://doi.org/10.1016/B978-0-08-102089-0.00015-7.
Pires, G. D., Stanton, J., \& Stanton, P. (2011). Revisiting the substantiality criterion: From ethnic marketing to market segmentation. Journal of Business Research, 64(9), 988-996. https://doi.org/10.1016/j.jbusres.2010.11.022.

Pituch, K. A., \& Stevens, J. (2016). Applied multivariate statistics for the social sciences: analyses with SAS and IBM's SPSS (6th ed.). New York: Routledge/Taylor \& Francis Group.

Rajaobelina, L., Brun, I., \& Toufaily, É. (2013). A relational classification of online banking customers. International Journal of Bank Marketing, 31(3), 187-205. https://doi. org/10.1108/02652321311315294.

Rod, A., \& Čermáková, K. (2016). Retail banking in the Czech Republic a comparison of consumer prices between 2011 and 2014. International Journal of Economic Sciences, 5(2). https://doi.org/10.20472/ES.2016.5.2.003.

Řezanková, H., \& Löster, T. (2013). Cluster analysis of households characterizes by categorical indicators. E\&M Ekonomie a Management, 16(3), 139-147.

Schiffman, L. G., \& Kanuk, L. L. (2007). Consumer behavior (9th ed.). Upper Saddle River, NJ: Pearson Prentice Hall.

Sun, S. (2009). An Analysis on the Conditions and Methods of Market Segmentation. International Journal of Business and Management, 4(2), 63-70. https://doi.org/10.5539/ijbm.v4n2p63.

Tahal, R., Formánek, T., \& Mohelská, H. (2017). Loyalty programs and personal data sharing preferences in the Czech Republic. E\&M Ekonomie a Management, 20(1), 187-199. https://doi.org/10.15240/tul/001/2017-1-013.

The World Bank. (2018). The little book on financial inclusion. Retrieved from https:// openknowledge.worldbank.org/bitstream/ handle/10986/29654/LDB-FinInclusion2018.pdf.

TNS opinion \& social. (2016). Special Eurobarometer 446: Financial Products and Services. Retrieved from http://ec.europa. eu/commfrontoffice/publicopinion/index.cfm/ ResultDoc/download/DocumentKy/74150.

Van Dijk MC, \& Centre for European Policy Studies. (2012). Market study of the current state of play in Member States regarding initiatives in bank fee transparency and comparability in personal current bank accounts. Retrieved from https://www.ceps.eu/system/files/1912012_ market_study_en.pdf.

van Schaik, P., Luan Wong, S., \& Teo, T. (2015). Questionnaire layout and national 


\section{Finance}

culture in online psychometrics. International Journal of Human-Computer Studies, 73, 5265. https://doi.org/10.1016/j.ijhcs.2014.08.005.

Wind, Y. (2008). Market segmentation. In The Marketing Book (pp. 222-244). https:// doi.org/10.1016/B978-0-7506-8566-5.50015-7.

Windle, P. E. (2010). Secondary Data Analysis: Is It Useful and Valid? Journal of PeriAnesthesia Nursing, 25(5), 322-324. https://doi.org/10.1016/j.jopan.2010.07.005.

Yankelovich, D., \& Meer, D. (2006). Rediscovering Market Segmentation. Harvard Business Review, 12.

Zhang, T., Ramakrishnan, R., \& Livny, M. (1996). BIRCH: an efficient data clustering method for very large databases. In Proceedings of the 1996 ACM SIGMOD International Conference on Management of Data - SIGMOD '96 (pp. 103-114). https://doi. org/10.1145/233269.233324.
Zuccaro, C., \& Savard, M. (2010). Hybrid segmentation of internet banking users. International Journal of Bank Marketing, 28(6), 448-464. https://doi. org/10.1108/02652321011077698.

Ing. Ivan Soukal, Ph.D. University of Hradec Králové Faculty of Informatics and Management Department of Economics Czech Republic ivan.soukal@uhk.cz

Mgr. Jan Draessler, Ph.D. University of Hradec Králové Faculty of Informatics and Management Department of Informatics and Quantitative Methods Czech Republic jan.draessler@uhk.cz 


\section{Abstract}

\section{HOW DOES A RETAIL PAYMENT ACCOUNT CONSUMER CHANGES OVER TIME? USAGE RATE BEHAVIORAL SEGMENTATION FROM 2010 TILL 2016 IN THE CZECH REPUBLIC}

\section{Ivan Soukal, Jan Draessler}

The paper is focused on retail payment account consumers with account access via e-banking. Firstly, the goal is to provide payment account usage profiles at the level of payment instruments. Secondly, to assess the development of identified profiles during the crisis and post-crisis year 2010-2016 in the Czech Republic. The two-step cluster analysis sample segmented 16,392 individual payment account usage records. Three clusters were identified: price-driven, active, and low balance/overdraft user. The clusters were mainly separated by an ATM usage and average balance. Payment instruments showed a less significant difference. The first cluster showed exclusive preference of own bank's ATM network. The second cluster manifested the highest usage frequencies and the broadest range of services. The third cluster had average account balance below zero with most of the consumers declaring an average balance from $€-925$ to $€ 370$. A steady trend of change was found regarding the demand structure. The price-driven profile was a mainstream consumer segment till 2014. The active consumer segment became dominant in 2015 due to a steady trend of price-driven profile share loss. The third cluster's share remained stable over the surveyed period. The next change in consumer typology was related to the usage rate. All clusters showed an increase in ATM usage over time. Price-driven cluster steadily increased ATM withdrawal abroad from technical zero to 0.4 per month. Active profile and low balance/overdraft user increased domestic ATM usage by almost one withdrawal per month. Direct payments showed an increase over time as well. Direct payments shared trend of increase in average by one payment per month, in a case of the price-driven profile by two.

Key Words: Consumer, segmentation, payment account, cluster analysis, datamining.

JEL Classification: C38, G21.

DOI: 10.15240/tul/001/2019-3-009 